We thank Dr M J Glasson for permission to report the cases.

\section{References}

1 Wolff G. Familial congenital diaphragmatic defect: review and conclusion. Hum Genet 1980:54:1-5.

2 Cranc JP. Familial congenital diaphragmatic hernia. Clin Genet 1979:16:244-52.

3 Arad I. Lijovetsky GC. Staninsky R. Laufer N. Cohen T. Diaphragmatic defects in children of consanguinous parents. Hum Genet 1980;55:275-7.

+ Hauschild VR. Congenital diaphragmatic hernia from the human genetic viewpoint. Kinderaerztl Prax 1982:50:16-20.

5 Gencik A, Moser H. Gencikova A. Kehrer B. Familial occurrence of congenital diaphragmatic defect in three families. Helv Paediatr Acta 1982:37:289-93.

- Passarge E. Halsey H. German J. Unilateral agenesis of the diaphram. Hum Genet 1968:5:226-30.

${ }^{7}$ Mertins H. Uber eine familiare Zwerchfellmibildung. Zentralbl Gynaekol 1952:74:951-5.

${ }^{*}$ Phillip EE. Skelton MO. Congenital diaphragmatic hernia in siblings. Br Med J 1952:i:1283-4.

${ }^{9}$ Daentl DL. Passarge E. Familial agenesis of the diaphragm. Birth Defects 1972:8:24-6.

11' Wolff G. Bohn N. Pringschein W. Congenital defects at the diaphram in siblings. Monatsschr Kinderheilkd 1980:128:412-4.

"Turpin R, Petit P. Chigot P. Lafourcade J, de Barochez Y. Hernie diaphragmatique congenital de type embryonnaire. Coincidence chez deux cousins germains de cette malformation isoléc. Ann Pediatr 1959:35:272-9.
12 Gualandri V. Lalatta F. Orsini GB. Zorzoli A. Bertagnoli L. Gallicchio A. Diagnostic prenatal d'un cas de repitition familiale. D’agenesie unilateral du diaphragme. J Genet Hum 1983:31:125-31.

13 Norio R. Kaaiainen H, Rapola J. Herva R. Kekomari M. Familial congenital diaphragmatic defects. Am J Med Genet 1984:17:471-83.

14 Watanatiitan S. Congenital diaphragmatic hernia in identical twins. J Pediatr Surg 1983:18:628-9.

15 Butler N. Claireaux AE. Congenital diaphragmatic hernia as a cause of perinatal mortality. Lancet 1962;i:659-63.

in Stauffer UG. Rickham PP. Congenital diaphragmatic hernia and eventration of the diaphragm. In: Rickham PP, Lister JP, Irving IM. eds. Neonatal surgerv. 2nd ed. London: Butterworths. 1978:163-78.

17 Harrison MR. Delorimer AA. Congenital diaphragmatic hernia. Surg Clin North Am 1981:61:1023-35.

is David TJ. Parker VM. Illingworth CA. Diaphragmatic hernia in Avon. J Med Genet 1980:17:135.

${ }^{14}$ David TJ. Illingworth CA. Diaphragmatic hernia in the southwest of England. J Med Genet 1972:13:253-62.

20 Barry JE. Danks DM. Anticonvulsants and congenital abnormalities. Lancet 1974:ii:48-9.

2 Edwards JH. The simulation of Mendelism. Acta Genet 1960:10:63-70.

Correspondence and requests for reprints to $\mathrm{Dr} \mathrm{A} \mathrm{H}$ Lipson, Birth Defects Unit, Royal Alexandra Hospital for Children, Camperdown, NSW 2050, Australia.

\title{
A case of suspected teratogenic holoprosencephaly
}

\author{
M STABILE*,A BIANCO*,S IANNUZZI†,M C BUONOCORE‡,AND \\ V VENTRUTO*
}

* Servizio Genetica Medica, Ospedale Cardarelli; †Divisione Pediatria, Ospedale San Paolo; and $¥$ Settore di Neuroradiologia, Ospedale Santobono, Napoli, Italy.

SUMMARY A case of holoprosencephaly is reported in which the mother was prescribed high doses of oestroprogestins during the first 5 months of the pregnancy. Investigation of the family failed to reveal any sign of physical abnormality. A normal karyotype was detected in the proband. The authors suggest that this case may shed some light on the normal and abnormal way in which embryonic fields develop.

The action of teratogenic factors in the aetiology of holoprosencephaly has been studied experimentally using various animals (amphibia, birds, and mammals) and different agents (surgical removal of the prechordal mesoderm or its destruction by localised $x$ irradiation, vitamin A excess, etc). ${ }^{12}$

The great majority of reports of this condition in man refer to cases with various chromosomal abnormalities, ${ }^{3-7}$ or Mendelian aetiology with autosomal dominant transmission in some families ${ }^{x-10}$ and autosomal recessive in others. ${ }^{111}$

Only a very few reported cases ${ }^{12}$ have well documented teratogenic mechanisms as causative factors. In the other cases Mendelian or chromosomal aetiology cannot be ruled out.

We report a case of alobar holoprosencephaly with a known exposure to a teratogenic agent.

\section{Case report}

The proband (fig 1) was a term newborn male (birth weight $3.5 \mathrm{~kg}$, head circumference $40 \mathrm{~cm}$ ) who died 


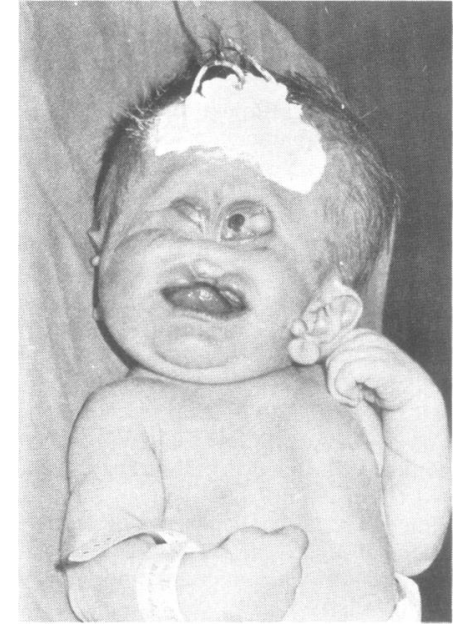

FIG 1 The proband.

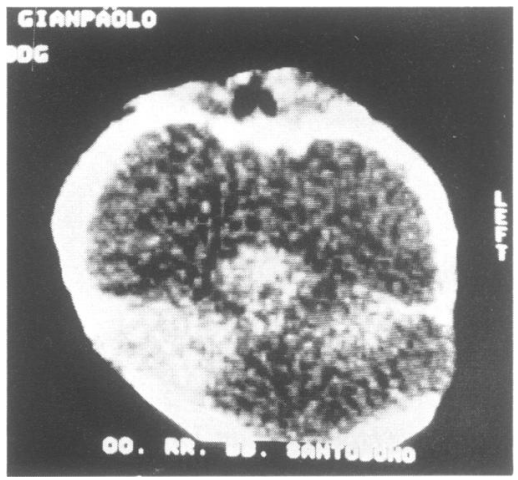

FIG 2 CT scan showing a large single ventricle.

a few days after birth. He had cebocephaly, hypotelorism, bilateral cleft lip and palate, a nose with a single nostril, hydrocephalus, and left iris coloboma. The karyotype was a normal $46, X Y$. Serum tests for toxoplasma, rubella, cytomegalovirus, and syphilis were negative. At necropsy a large single ventricle with absent forebrain and its embryological derivatives, optic tracts, and olfactory bulbs were observed.

The family history was not informative. The mother and father were aged 28 and 32 years respectively at the time of conception. They had a normal girl of 9 years. The interpupillary distance in all three first degree relatives was normal and cranial radiographs did not reveal any facial anomaly. The mother was given allyloestrenol (Gestanon), six $5 \mathrm{mg}$ tablets per day, and dihydrogesterone
(Dufaston Depot), one $100 \mathrm{mg}$ injection im per day. $\stackrel{\stackrel{D}{?}}{?}$ Both drugs were given throughout the first 5 months $\Rightarrow$ of pregnancy. The drugs were prescribed by an $\stackrel{?}{?}$ obstetrician because of spontaneous abortion in the? previous pregnancy.

\section{Discussion}

The question of the teratogenicity in man of oestrogens and progestins, apart from the sexual $\stackrel{\circ}{-}$ differentiation of the fetus, ${ }^{13}{ }^{14}$ is still controversial. $\vec{\omega}$ In a large series of retrospective studies the use of oestrogen and progesterone during the early months of pregnancy has been found to be significantly associated with neural tube defect, ${ }^{15}$ VACTERL $N$ association, ${ }^{16}$ limb reduction defect,,${ }^{17}$ and congenit- ${ }_{-}$ al heart disease. ${ }^{18}$ Holoprosencephaly was reported $\vec{P}$ by Batts et al $^{19}$ but the patient also had trisomy $\mathrm{D}$. 음

In the prospective survey of Hook et $a l^{20}$ in which 50282 pregnancies were studied, a higher incidence $\rightarrow$ of malformations was found after both early and late을. exposure to sex hormones in pregnancy. In contrast, $\overrightarrow{\vec{\bullet}}$ a small number of prospective and retrospective $\mathscr{C}_{\infty}$ studies have failed to confirm the teratogenicity of these drugs. 2122

The embryotoxicity of oestrogens and progestins has been proved in mammals such as mice, ${ }^{23}$ rats, ${ }^{23} \bar{\partial}$ and mus rattus albinus. ${ }^{24}$ The most favoured interpretation of the facts is a teratogenic potential $\stackrel{\circ}{\Omega}$ conditioned by genetic and other exogenous $\overrightarrow{\vec{F}}$ factors.

\section{References}

1 Cohen MM, Gorlin RJ. Genetic considerations in a sibship of cyclopia and clefts. Birth Defects 1969;V(2):113-8.

2 Evans HE, Ingalls TH, Binns W. Teratogenesis of craniofacial malformations in animals. III. Natural and experimental cepha- 3 lic deformities in sheep. Arch Environ Health 1966;13:706-9.

${ }^{3}$ Emberger JM, Marty-Double C, Pincemin D, Caderas de $ᄋ$ Kerleau J. Holoprosencephaly due to $69, \mathrm{XXX}$ triploidy in a 5 month-old fetus. Ann Genet (Paris) 1976;19:191-3.

4 Fujimoto A, Ebbin AJ, Towner JW, Wilson MG. Trisomy 13 in two infants with cyclops. J Med Genet 1973;10:294-6.

${ }^{5}$ Hunter AGW, Ray M, Langston C. Cebocephaly in an infant 을. with trisomy 18. J Med Genet 1977;14:291-2.

${ }^{6}$ Lang AP, Schlager FM, Gardner HA. Trisomy 18 and cyclopia. $\widehat{N}$

Teratology 1976;14:195-204.
${ }^{7}$ McDermott A, Insley J, Barton MA, Rowe P, Edwards JH, 요 Cameron AH. Arrhinencephaly associated with a deficiency involving chromosome 18. J Med Genet 1968;5:60-7.

* Cantú JM, rragoso R, Garcia-Cruz D, Sanchez-Corona J. Dominant inheritance of holoprosencephaly. Birth Defects $\stackrel{\varrho}{\mathrm{C}}$ 1978;XIV(6B):215-20.

9 Cohen MM, Jirasek JE, Guzman RT, Gorlin RJ, Patterson MQ. Holoprosencephaly and facial dysmorphic nosology, etiol- $\square$ ogy, and pathogenesis. Birth Defects 1971;7:136-42.

10 Greebe H. Zuer Aetiologie der Arhinencephalie. Erbarzt $\frac{\vec{D}}{\mathbb{D}}$ 1944;12:138-42.

11 De Myer W, Zeman W, Palmer CD. Familial alobar holoprosencephaly with median cleft lip and palate; report of patient with 46 chromosomes. Neurology (Minneap) 1963;13:913-8. 
12 Mollica F, Pavone L, Nuciforo G, Sorge G. A case of cyclopia. Role of environmental factors. Clin Genet 1979;16:69-71.

13 Bongiovanni AM, Di George AM, Grumbach MM. Masculinization of the female infant with estrogenic therapy alone during gestation: four cases. J Clin Endocrinol 1959;19:1004-8.

14 Wilkins L. Masculinization of the female fetus due to the use of orally given progestins. JAMA 1960;172:1029-32.

15 Greenberg G, Inman WHW, Weatherall JAC, Adelstein AM. Hormonal pregnancy tests and congenital malformations. $\mathrm{Br}$ Med J 1975;ii:191-2.

16 Nora JJ, Nora AH. Preliminary evidence for a possible association between oral contraceptives and birth defects. Teratology 1973;7:24A.

17 Janerich DT, Piper JM, Glebatis DM. Oral contraceptives and congenital limb reduction defects. N Engl J Med 1974;291:697700.

18 Janerich DT, Dugan JM, Standfast SJ. Congenital heart disease and prenatal exposure to exogenous sex hormones. $\mathrm{Br} \mathrm{Med} \mathrm{J}$ 1977;i: $1058-60$.

19 Batts JA, Punnett HH, Valdes-Dapena M, Coles JW, Green WR. A case of cyclopia. Am J Obstet Gynecol 1972;112:657-61.
21) Hook EB, Heinonen OP, Shapiro S, Slone D. Maternal exposure to oral contraceptives and other female sex hormones: relation to birth defects in a prospectively ascertained cohort of 50,282 pregnancies. Teratology 1974:9:21-2A.

${ }^{21}$ Robinson SC. Pregnancy outcome following oral contraceptives. Am J Obstet Gynecol 1971;109:354-8.

22 Wilson JG. Embryotoxicity of drugs in man. In: Wilson JG, Fraser FC, eds. Handbook of teratology. Vol 1. London, New York: Plenum Press, 1977:324-7.

23 Andrew FD, Christensen HD, Williams TL, Thompson MG, Wall ME. Comparative teratogenicity of contraceptive steroids in mice and rats. Teratology 1973;7:11-12A.

${ }^{24}$ Lo Scalzo B, Agrusta A, Agrusta M, Crisci A, Genovese L, Marino M. Ricerche di fetoembriotossicità sull'allilestrenolo nel Mus rattus albinus. Riv Toss Sper Clin 1983;13:9-19.

Correspondence and requests for reprints to Professor V Ventruto, Servizio di Genetica Medica, Ospedale A Cardarelli, 80131 Napoli, Italy.

\title{
Tracheo-oesophageal anomalies in the Goldenhar anomalad
}

\author{
A MENDELBERG, I ARIEL, P MOGLE, AND I ARAD \\ Departments of Pediatrics, Pathology, and Radiology, Hadassah University Hospital, Mount Scopus, \\ Jerusalem, Israel.
}

SUMMARY A case of the Goldenhar anomalad is presented with a previously undescribed association with oesophageal atresia and tracheo-oesophageal fistula. This is the second instance of a tracheobronchial-oesophageal communication being found in association with the anomalad. Awareness of this combination may facilitate future diagnosis and treatment of the anomaly.

The Goldenhar anomalad is an association of facial and auricular anomalies resulting from errors in morphogenesis of the first and second branchial arches, accompanied sometimes by vertebral, ocular, and visceral malformations. ${ }^{1}$ We describe a case with previously undescribed anomalies including tracheo-oesophageal fistula, oesophageal atresia, and hypoplasia of the cerebellum.

\section{Case report}

A $2.025 \mathrm{~kg}$ female infant was delivered after 36 weeks of uneventful gestation to a 24 year old mother. The parents were unrelated Sephardic Jews and both they and their two children were normal and in good health. The Apgar scores were 6

Received for publication 30 May 1984.

Accepted for publication 11 July 1984. and 9 at 1 and 5 minutes respectively. Increasing dyspnoea and excessive salivation were soon noted and an attempt to pass an orogastric catheter was unsuccessful.

On examination the baby was noted to have an asymmetrical facies with maxillomandibular hypoplasia, bilateral preauricular skin tags, and microphthalmia with lipodermoids on both lower palpebrae (figure a). The cardiac impulse was felt over the right chest while breath sounds were heard over the left side only. The rest of the examination was considered normal. On chest $x$-ray a hyperinflated left lung with a complete rightward shift of the mediastinal structures and opacification of the right chest was seen. Extranumerary ribs and hemivertebrae of D1 to D4 were present. The visible tip of the orogastric catheter at D3 and the presence of gastric air suggested the presence of oesophageal atresia with a tracheo-oesophageal fistula. Bronchography showed a complete absence of the right bronchial tree (figure b). The baby died at 20 hours of age.

At necropsy the right lung and the right mainstem bronchus were absent. The left lung had three lobes. The upper portion of the oesophagus was separated from the lower half and ended blindly. The lower portion opened into the trachea. The cardiac chambers and valves were normal. The ductus arteriosus and the foramen ovale were patent. The pulmonary trunk divided into two branches, both supplying the 